${ }^{*}$ Anisfield School of Business, Ramapo College of New Jersey

\title{
Financial Constraints and the Response of Business Investment to Monetary Policy Shocks
}

\begin{abstract}
In this study I investigate what impact monetary policy shocks have on firms' fixed investment, the less liquid portion of gross investment that requires more planning. I account for firms facing financial constraints firms by utilizing a common measure of asset size, which is used in previous literature. I use two exogenous, continuous series of monetary policy shocks to show that constrained firms have statistically different responses to policy than unconstrained firms. Specifically, I find that constrained firms' fixed investment significantly responds more to monetary policy shocks than unconstrained firms.
\end{abstract}

Keywords: Business Investment, Monetary Policy

JEL Classification: G31, E52

\section{Introduction}

Business investment and monetary policy are both believed to be important sources of aggregate demand disturbances. Capital levels below potential have historically created a "host of economic ills" such as heightened unemployment and lower output throughout industrialized economies (see Chirinko (1993)) and monetary policy has a variety of real effects on an economy (see Bernanke and Blinder (1992) and Bernanke and Gertler (1994)). This paper empirically analyzes how monetary policy affects business fixed investment for firms facing financing constraints in particular. I estimate how monetary policy shocks influence fixed 
investment for firms who can easily access outside capital versus those who face difficulties.

The motivation behind this paper comes from Fazzari et. al (1988) who finds that firms facing financing constraints have investment patterns that are sensitive to internal factors such as average tax burdens and marginal tax rates. These factors are idiosyncratic to each firm, whereas in my study I broaden the scope to unforeseen shocks to monetary policy.

Two papers explore how monetary policy and investment in inventories are linked. Kashyap et al. (1994) find that during recessions driven by tight credit firms' inventory investment is positively influenced by sales indicating sensitivity to cash inflows for constrained firms. "Constrained firms" - defined by the absence of rated public debt - are more positively influenced by past sales when a recession is driven by tight monetary policy. Their conclusion is that constrained firms' inventory investment is positively influenced by their internal cash where unconstrained firms are not.

Gertler and Gilchrist (1994) compare the movement of inventories for firms based on asset size. The authors examine time periods associated with increases in the Federal Funds rate of 75 basis points or more as well as 6 distinct dates where the Federal Reserve generated large monetary disturbances not due to output fluctuations ("Romer Dates"). These dates are when the Federal Reserve purposefully pushed the economy into a recession to stave off inflation (Romer and Romer, 1990). Gertler and Gilchrist (1994) find that during periods of tight credit, small firms sell off inventories and large firms borrow and accumulate them. They further note that small firms reduced inventory more when their sales dropped during these periods.

A third paper looks again at the link between monetary policy and firms facing different constraints, however, the focal point is in bank loans and the broad credit channel of monetary policy. Oliner and Rudebusch (1996) look for evidence of a broad credit channel of monetary policy by estimating the response of gross investment for firms based on different asset sizes in response to cash flows through borrowing. They conduct their analysis around the "Romer Dates" and periods with increases in the fed funds rate of 75 basis points or more. Their first empirical finding is that the quantity of loans decreases for all parties during these periods of tight credit; this behavior is not unique to firms facing financing constraints. The difference they find is that constrained firms' gross investment is sensitive to changes in their cash flow around periods of tight credit. This result differs from Kashyap et al (1994) and Gertler and Gilchrist (1994). 
My study will focus on fixed investment for firms facing different financing constraints in response to monetary policy shocks and not particular periods of increases in the fed funds rate. Moreover, rather than using discrete "Romer Dates" I employ a continuous series of policy shocks. According to Hodrick and Prescott (1997), fixed investment accounts for $14.2 \%$ of Gross National Product and has a correlation with it of 0.714 . This is higher than the correlation with inventory investment of 0.507. My other motivation is to understand the financing of fixed investment. Blinder and Maccini (1992) find that there is little empirical evidence that real interest rates influence investment. This suggests there are other avenues that influence the financing of fixed expenditures.

I assume that cash flow will be a significant determination of investment. Two of the previously referenced papers conclude that sales and inventory changes for both constrained and unconstrained firms impact real investment. This is further supported by Fazzari and Petersen (1993) who found that it is costly for firms to change their level of fixed investment and that firm cash flow determine investment. They also explore how firms smooth investment by offsetting cash flows by adjusting net working capital (e.g. accounts receivable, cash, and inventories less accounts payable and short term debt). The extent of the cash offset depends on the size of the firm's balance sheet.

My hypothesis is this: the amount of fixed investment a firm has is an intertemporal maximization problem by choosing projects with the highest marginal value. This is true for both financially constrained firms and unconstrained firms (see Winter (1998)). These decisions are driven by their cash flow which also affects their net working capital. Fazzari and Petersen (1993) find that net working capital is three times more variable than fixed capital investment when shocks to cash flow are present. In order to maintain the steady path of fixed investment, firms will adjust their net working capital to finance the fixed investment. This would most likely include increasing short term debt or selling off inventories.

I further hypothesize that firms that do not face financing constraints can easily smooth fixed investment during bad times by using debt or retained cash. Firms that do face such constraints have to use their retained cash or bank loans or by selling inventory to acquire cash. Gertler and Gilchrist (1994) find that after periods of tight credit small firms sell off inventories while large firms borrow and acquire inventories. It could be that constrained firms smooth their investment paths by selling off the more liquid assets to maintain their more costly endeavors. 
Due to these potential differences, I empirically test the response of fixed investment to monetary policy shocks. I choose shocks because they are exogenous shifts in policy. This eliminates any endogeneity issues present in using the absolute change in the Federal Funds rate which is in response to macroeconomic signals (such as output which is a function of investment). Unlike previous studies, I utilize two different methods of measuring a policy shock: 1) VAR residuals from a model specification built by Christiano et al (1996), and 2) the Romer series. The previous studies all used the Romer dates and/or periods where the Federal Funds rate increased by 75 basis points or more. I do not use these methods for a few reasons: first, there are very few Romer dates and my data is more current; second, as noted by Gertler and Gilchrist (1994), the Romer dates precede significant downturns in real economic activity which results in highly significant results due to the intentional actions of the Federal Reserve; and third, my two measures of policy shocks are continuous series. Past studies only looked at movements around bad economic times and largely ignore the time periods in between. Kashyap et al (1994) even note that there is little evidence of inventories being sensitive to financial factors (such as cash flows) outside of recessions. I believe that policy shocks exist outside of dramatic periods of tight credit and constrained firms would still be more sensitive to monetary policy changes.

In my paper I find that firms classified as "financially constrained" do have a more significant response in their fixed investment expenditure patterns due to monetary policy shocks to interest rates compared to "unconstrained" firms. This response is significant and larger in magnitude than that of their unconstrained counterparts. This holds for both measures of monetary policy shocks as well as alternative time period measurements. I provide a detailed explanation of the important literature in section II. A description of the data employed and a baseline test of firm behavior follows in section III. The regression used to test the response to policy shocks is presented along with results in section IV. Section V concludes the paper, tables and figures are at the end.

\section{Background}

Monetary policy affects firms in three ways: through interest rates, the bank lending channel, and the balance sheet channel. The bank lending channel, as explained by Bernanke and Blinder (1992), shows that monetary policy's effect on the volume of reserves directly affects credit. A monetary tightening reduces reserves which reduces overall credit. This means that as loans terminate, new loans may not be made. The authors use this as the explanation why loans respond slowly to such policy innovations, however, they do react accordingly. 
Bernanke and Gertler (1995) define the balance sheet channel as the mode of transmission that affects firms' net worth. This can be done through short term debt, floating rate debt, collateral or consumer spending. Monetary tightening raises the cost of debt so floating rate debt would adjust and short term debt will cost more to reissue. Collateral value moves opposite of interest rates so a monetary tightening would diminish borrowing power if collateral is typically used. Consumer spending falls with monetary tightening as the interest rate increases (opportunity cost of money increases) which on the whole decreases firms' cash inflows.

Firm reaction to monetary policy is well defined; each of these mechanisms link policy to the means of raising capital for firms. Considering that raising capital is crucial for investment spending which increases output, this is an important interaction to note. Furthermore, there is plenty of heterogeneity in firms' reactions. Under the lending channel, firms that heavily rely on bank loans will feel the effects more whereas firms that have easy access to external capital markets (debt/stock issuance) may not. Under the balance sheet channel, firms that rely on collateral for borrowing or are more sensitive to their inflows to fund future investment will be affected more by policy innovations. These examples make it clear that not all firms will react in the same way which leaves one question unanswered: how do different types of firms react to monetary policy? More specifically, how do firms with different means of raising funds react? This requires a collection of financial literature discussing what it means to be financially constrained.

There have been predominantly three studies that focus on firm behavior in reaction to monetary policy shocks while accounting for differences in their financial constraints. Gertler and Gilchrist (1994) separated firms into two categories, large and small, based on the firms' asset size and sales. They analyzed the response of inventories, sales, and short term debt to the Romer episodes and changes in the fed funds rate. Their results indicate that small firms contract in inventories and credit flow. Kashyap, Lamont and Stein (1994) classified firms based on bond ratings. They found that firm inventories are sensitive to liquidity for firms without bond ratings during periods of monetary tightening surrounding the Romer episodes. The third paper, by Oliner and Rudebusch (1996), classify firms based on their asset size similar to that of Gertler and Gilchrist (1994). They analyzed the changes in bank and nonbank debt for each firm category in response to the Romer episodes and changes in the fed funds rate. Interestingly, they found that bank debt does not behave significantly different from nonbank debt. They found that credit is channeled away from small firms and to large firms for both, bank and nonbank debt, following a monetary contraction. These three studies have 
been followed by numerous papers attempting to further identify criteria that are indicative of financial constraints at the firm level.

Whether or not a firm is deemed financially constrained simply reflects the difficulties firms face while raising external funds. Some firms rely on bank lines of credit or retained income while others may have a seemingly endless supply of securities that can be issued. In either case, it is interesting to separate firms by such characteristics to capture the possible heterogeneity of the extremes. The literature focusing on constraints primarily analyzes its effects on firm behavior and financial management beginning with Fazzari, Hubbard and Petersen (1988). They determine that investment spending varies with available internal funds. Numerous papers followed that expanded on this topic including Kaplan and Zingales (1997), Cleary (1999), Alti (2003), and Almeida and Campello (2006).

The literature does not cover the response of fixed investment to policy shocks. This form of investment has a longer time horizon than inventories and requires more foresight and planning. I assume that unexpected shocks to policy, an observation that may indicate a significant bettering or worsening of the economy will have an impact to this investment. I add to the literature by regressing this relationship and find that constrained firms do have a more negative reaction to policy shocks.

\section{Firm Data and a Baseline Test of Firm Behavior}

I use existing criterion that defines a firm as financially constrained to test the response of investment growth to monetary policy shocks. I first test cash retention behavior to show that financially constrained firms hold more cash on their balance sheet from their cash inflows than unconstrained firms. To do so, I consider the sample of manufacturing firms (Standard Industrial Classification [SIC] codes 2000-3999) over the 1971 - 2008 periods as available through COMPUSTAT and the Center for Research in Security Prices (CRSP). The sample starts in 1971. I eliminate firm-years with asset growth of over $100 \%{ }^{1}$, years where cash holdings exceed total assets, and years with missing data values. The resulting sample contains 5,008 separate firms and 85,866 firm-year observations.

The approach I employ to test whether or not a "constrained" firm is sensitive to its earnings is similar to that employed by Almeida, Campello and Weisbach (2004). In their study, they claim that financially constrained firms should retain

\footnotetext{
1 Observations of this kind are indicative of merger and acquisition behavior
} 
a significant portion of their cash inflows to fund future investment decisions. This is compatible to what is expected of firms who have difficulties raising funds. To test this, I estimate their regression for cash holdings:

$$
\Delta \text { CashHoldings }_{i, t}=\beta_{0}+\beta_{1} \text { CashFlow }_{i, t}+\beta_{2} Q_{i, t}+\beta_{3} \text { Size }_{i, t}+\varepsilon_{i, t}
$$

CashHoldings is defined as the ratio of holdings of cash and marketable securities to total assets and the change is first-difference; CashFlow is the ratio of earnings before extraordinary items and depreciation less dividends to total assets; $Q$ is the market to book ratio and Size is the natural log of total assets. The sign on CashFlow is expected to be significantly positive for "constrained" firms because it captures the sensitivity of cash. $Q$ is included as a contemporaneous measure of growth opportunities while Size is included to capture any effect of economies of scale.

To estimate the model, I split the sample of firms into constrained and unconstrained groups using asset size as criterion for being classified as constrained or unconstrained. ${ }^{2}$ I separate the firms by asset size similar to Almeida, Campello and Weisbach (2004). Firms in the sample are ranked based on the size of their (logged) assets. Firm-year observations in the bottom (top) three deciles are classified as constrained (unconstrained). The intuition is that smaller firms tend to be young while larger firms are well established; smaller firms in this manner are presumed to be affected more by capital market imperfections. The end sample contains 25,175 observations for each of the constrained firms and unconstrained firms.

The importance of this regression is to identify those firms with lower assets that are assumed to have difficulties raising capital and therefore retain more of their cash inflows. Table 1 shows the results from the above specification which identifies the portion of cash inflows that are withheld. If a firm is indeed constrained, it is expected that they retain cash, more so than their unconstrained counterparts, in order to fund future investment. The coefficient for CashFlow confirms that financially constrained firms retain a significant portion of their cash inflows whereas unconstrained firms do not. Firms that are classified as financially constrained retain $18.8 \%$ of their cash flows. What is important is that financially constrained firms retain significant portions of their cash flows while the unconstrained do not.

2 Kashyap et al (1994) use the existence of short term and long term debt ratings. The sample I acquired contained a very small amount of usable ratings so I have omitted them. 
Table 1: Behavioral Test

\begin{tabular}{|c|c|c|}
\hline Left Hand Side Variables & $\begin{array}{l}\text { G(Cash Holdings) } \\
\text { Asset Size: FC }\end{array}$ & $\begin{array}{l}\text { G(Cash Holdings) } \\
\text { Asset Size: NC }\end{array}$ \\
\hline \multirow[t]{3}{*}{ Cash Flow } & $0.188^{* * *}$ & 0.000 \\
\hline & $(0.00)$ & $(0.99)$ \\
\hline & 0.01 & 0.03 \\
\hline \multirow[t]{3}{*}{ Q } & 0.000 & 0.000 \\
\hline & $(0.39)$ & $(0.83)$ \\
\hline & 0.00 & 0.00 \\
\hline \multirow[t]{3}{*}{ Size } & $0.052^{* * *}$ & 0.004 \\
\hline & $(0.00)$ & $(0.25)$ \\
\hline & 0.01 & 0.00 \\
\hline \multirow[t]{3}{*}{ Constant } & $-0.189 * * *$ & $-0.056^{* *}$ \\
\hline & $(0.00)$ & $(0.05)$ \\
\hline & 0.02 & 0.03 \\
\hline Observations & 25.175 & 25.175 \\
\hline R-squared & 0.010 & 0.000 \\
\hline $\mathrm{F}$ & 89.00 & 0.455 \\
\hline \multicolumn{3}{|l|}{ pval in parentheses } \\
\hline${ }^{* *} p<0.01,{ }^{* *} p<0.05,{ }^{*} p<0.1$ & & \\
\hline
\end{tabular}

Source: my own calculations

\section{The Regression and Alternative Specifications}

Figure 1: Fixed investment growth for constrained/ unconstrained firms

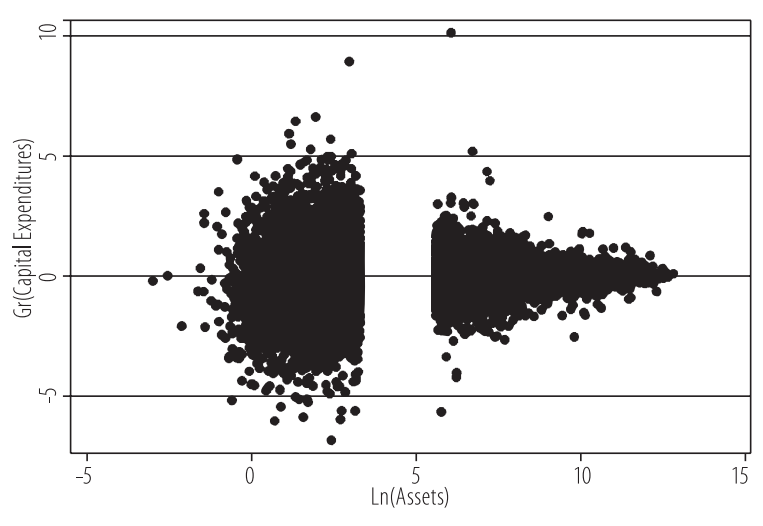

Source: my own calculations
Figure 1 shows a scatterplot of growth in fixed expenditures by asset size. Firms with lower assets have more variation in their spending. The separation of the two clusters is due to the constrained (unconstrained) firms representing the bottom (top) 30\% of the original sample of firms; the middle $40 \%$ is not represented here. Further, both clusters' growth in fixed spending appears symmetrical around zero with very few outliers. 
The regression that I use to test the investment response of constrained vs. unconstrained firms takes the following form:

$$
\Delta \operatorname{CapExp}_{i, t}=\sum_{j=1}^{k} \beta_{j} \operatorname{MPShock}_{(t-j)}+F C_{i}+F C_{i} \sum_{j=1}^{k} \beta_{j} \operatorname{MPShock}_{(t-j)}+\varepsilon_{i, t}
$$

The left hand side variable is the growth in a firm's capital expenditures ${ }^{3}$ over their reported fiscal year. The monetary policy shock variables are measured in three ways. I construct an annual average shock to coincide with the annual reporting of the capital expenditure variable, then a cumulative annual shock, and finally a biannual shock. I lag the policy shock for two years in total for each time measurement ${ }^{4}$. I consider an average and a cumulative measure for the annual shocks to see if over the course of a year some shocks cancel each other out, possibly negating its impact. I include a dummy variable to designate whether or not the firm is financially constrained based on its asset size, followed by interaction terms to observe how constrained firms behave differently than unconstrained firms.

I employ two measurements of monetary policy shocks for my right hand side variables. The first is that put forth by Romer and Romer (2004) ${ }^{5}$. Their series is the portion of intended policy decisions that are not due to current economic measures of output and inflation. Previously mentioned studies have used the "Romer Dates" for policy shocks. I use this series instead because it is continuous in nature and derived from the Greenbook forecasts, not Federal Open Market Committee minutes. These forecasts provide the information used by the Committee to make their intended policy recommendation. Particularly, it contains the Committee members' forecasts of inflation, real output growth, and the unemployment rate. The "Romer series" is the portion of the intended policy change not influenced by these variables and covers the period 1/1969 - 12/1996 and the value of these shocks is larger in magnitude for a monetary tightening versus a monetary easing.

The second measure is the VAR residuals proposed by Christiano, Eichenbaum and Evans (1996). I regress the Federal Funds rate on the log of Real GDP, the log of the GDP deflator, the PPI for crude energy (to capture a cyclically sensitive producer index), the negative log of non-borrowed reserves, and the log of total reserves. The data is quarterly and I use 4 lags. I then collect the residuals

\footnotetext{
3 Capital expenditures are scaled by the producer price index for nonresidential fixed investment.

4 Therefore " $k$ " is equal to 2 for annual shocks, and 4 for quarterly shocks.

5 Table 2 pg. 1064
} 
which represent the portion of policy that is independent from the macroeconomic variables.

The data in this regression requires some modifications because the policy shocks are very time specific. The firm data is calculated over the course of the fiscal year which is different for each firm. I have the month that the firm data is recorded, so the aggregation of shocks goes as follows: I associate 24 months of policy shocks prior to the month that the investment data was documented. For the Romer series, I then aggregate the monthly policy shocks into the annual and biannual combinations. The VAR shock is quarterly. I combine them using the quarter that contains the firm's fiscal year end as time period 0. Each quarter before that becomes the respective lag and I average and aggregate these shocks at annual and biannual intervals.

I first regress the growth in capital expenditures on the average annual monetary policy shock. The results from the Romer series and the VAR are in Table 2. The coefficients for the policy shocks across the whole sample are negative and significant for the second lagged year for both policy measures. The first lagged year is insignificant for the Romer series but significant and positive for the VAR at 0.0582 . This implies that within the first year of a policy shock, capital expenditures still increase by $5.82 \%$ over the entire sample. If capital expenditures are planned and financed over a lengthier time than liquid assets (such as inventories), then a firm's commitment to a project would continue even if a recent shock were to occur. The second lagged year coefficient is negative and significant for both the Romer series and the VAR series.

The interaction terms in Table 2 show that the first lagged year of policy shocks for constrained firms is significant in determining fixed spending. The coefficient for the VAR series is -0.0784 indicating a $7.84 \%$ decrease in constrained firms' capital expenditures in response to a $1 \%$ shock to the federal funds rate. The coefficient for the Romer series is -0.8233 indicating a $82.33 \%$ decrease in capital expenditure growth for the same shock. There is no significant change to capital expenditure growth in response to monetary policy shocks beyond the first year. 
Table 2: Annual Average Shocks

\begin{tabular}{|c|c|c|}
\hline Gr(Cap. Ex.) & VAR series & Romer Series \\
\hline \multirow[t]{3}{*}{$\mathrm{MP}(1)$} & $0.0582^{* * *}$ & 0.1046 \\
\hline & $(0.000)$ & $(0.290)$ \\
\hline & 0.011 & 0.099 \\
\hline \multirow[t]{3}{*}{$\mathrm{MP}(2)$} & $-0.0682^{* * * *}$ & $-0.4408^{* * *}$ \\
\hline & $(0.000)$ & $(0.000)$ \\
\hline & 0.011 & 0.098 \\
\hline \multirow[t]{3}{*}{ FC Dummy } & $-0.0698^{* * *}$ & $-0.0823^{* * *}$ \\
\hline & $(0.000)$ & $(0.000)$ \\
\hline & 0.008 & 0.011 \\
\hline \multirow[t]{3}{*}{$\mathrm{MP}(1)^{*} \mathrm{FC}$} & $-0.0784^{* * *}$ & $-0.8233^{* * *}$ \\
\hline & $(0.000)$ & $(0.000)$ \\
\hline & 0.015 & 0.134 \\
\hline \multirow[t]{3}{*}{$\mathrm{MP}(2) * \mathrm{FC}$} & 0.0151 & 0.0434 \\
\hline & $(0.293)$ & $(0.745)$ \\
\hline & 0.014 & 0.133 \\
\hline \multirow[t]{3}{*}{ Constant } & $0.0582^{* * *}$ & $0.0668^{* * *}$ \\
\hline & $(0.000)$ & $(0.000)$ \\
\hline & 0.005 & 0.008 \\
\hline Observations & 50.350 & 25,148 \\
\hline R-squared & 0.004 & 0.007 \\
\hline $\mathrm{F}$ & 38.42 & 32.98 \\
\hline
\end{tabular}

pval in parentheses

${ }^{* * *} p<0.01,{ }^{* *} p<0.05,{ }^{*} p<0.1$

Source: my own calculations

The next specification I use is a cumulative annual policy shock. I believe that capital expenditure is an investment that involves planning over a long time horizon. This alternative assumes that a positive shock during the year that is offset by a counteracting shock later in that same year may influence the investment decision process. I present the results from the Romer series and the VAR series in Table 3. All of the coefficients that were significant in the average annual shock are also significant for the cumulative shock.

I find that the coefficient for the first lagged year for the Romer series' interaction term is -0.2058 which is a $20.58 \%$ opposite shift in constrained firms' capital expenditures for a 1 percentage point shock cumulatively over the course of a year. I also find that the coefficient for the first lagged year for the VAR series is negative and significant at -0.0196 implying a $1.96 \%$ decrease in capital expenditures. The 
magnitude of the response is lower in the VAR specification than in the Romer specification, which is also what I found using the average shock calculation.

Table 3: Annual Cumulative Shocks

\begin{tabular}{|c|c|c|}
\hline Gr(Cap. Ex.) & VAR Series & Romer Series \\
\hline \multirow[t]{3}{*}{$\mathrm{MP}(1)$} & $0.0146^{* * *}$ & 0.0262 \\
\hline & $(0.000)$ & $(0.290)$ \\
\hline & 0.003 & 0.025 \\
\hline \multirow[t]{3}{*}{$\mathrm{MP}(2)$} & $-0.0171^{* * *}$ & $-0.1102^{* * *}$ \\
\hline & $(0.000)$ & $(0.000)$ \\
\hline & 0.003 & 0.024 \\
\hline \multirow[t]{3}{*}{ FC Dummy } & $-0.0698^{* * *}$ & $-0.0823^{* * *}$ \\
\hline & $(0.000)$ & $(0.000)$ \\
\hline & 0.008 & 0.011 \\
\hline \multirow[t]{3}{*}{$\mathrm{MP}(1)^{*} \mathrm{FC}$} & $-0.0196^{* * *}$ & $-0.2058^{* * *}$ \\
\hline & $(0.000)$ & $(0.000)$ \\
\hline & 0.004 & 0.034 \\
\hline \multirow[t]{3}{*}{$\mathrm{MP}(2)^{*} \mathrm{FC}$} & 0.0038 & 0.0108 \\
\hline & $(0.293)$ & $(0.745)$ \\
\hline & 0.004 & 0.033 \\
\hline \multirow[t]{3}{*}{ Constant } & $0.0582^{* * *}$ & $0.0668^{* * *}$ \\
\hline & $(0.000)$ & $(0.000)$ \\
\hline & 0.005 & 0.008 \\
\hline Observations & 50.350 & 25,148 \\
\hline R-squared & 0.004 & 0.007 \\
\hline $\mathrm{F}$ & 38.42 & 32.98 \\
\hline \multicolumn{3}{|l|}{ pval in parentheses } \\
\hline${ }^{* * *} p<0.01, * * 0<0.05,{ }^{*} p<0.1$ & & \\
\hline
\end{tabular}

Source: my own calculations

The last method I use is splitting up the shocks into biannual, 6-month intervals. I present the results for the Romer and the VAR series in Table 4. I find that the two lagged 6-month periods for the first year are both negative and significant for both the Romer series' and VAR series' constrained interaction terms. This timeframe has had consistent results across all specifications of policy shocks and lag structure.

The coefficients for the Romer series are -0.3920 and -0.5030 . I interpret this as a $39.2 \%$ opposite movement in constrained firms' capital expenditures for a 1 percentage point shock in the first 6 -month lag and a $50.3 \%$ opposite movement for a 1 percentage point shock within the 6 months prior. The coefficients for VAR series are -0.0375 and -0.0387 for the first two lags. This is a $3.75 \%$ opposite move- 
ment for a 1 percentage point shock in the first 6-month lag and a 3.87\% opposite movement for a 1 percentage point shock within the 6 months prior. The reaction of constrained firms' fixed spending for the Romer series has been consistently higher in magnitude than the VAR series.

Table 4: Biannual Shocks

\begin{tabular}{|c|c|c|}
\hline $\operatorname{Gr}($ Cap. Ex.) & VAR Series & Romer Series \\
\hline \multirow[t]{3}{*}{$\mathrm{MP}(1)$} & $0.0249 * * *$ & $0.1247^{* *}$ \\
\hline & $(0.009)$ & $(0.034)$ \\
\hline & 0.010 & 0.059 \\
\hline \multirow[t]{3}{*}{$\mathrm{MP}(2)$} & $0.0307^{* * *}$ & -0.0120 \\
\hline & $(0.000)$ & $(0.847)$ \\
\hline & 0.007 & 0.062 \\
\hline \multirow[t]{3}{*}{$\mathrm{MP}(3)$} & $-0.0374^{* * *}$ & $-0.1852^{* * *}$ \\
\hline & $(0.000)$ & $(0.001)$ \\
\hline & 0.009 & 0.057 \\
\hline \multirow[t]{3}{*}{$\mathrm{MP}(4)$} & $-0.0320^{* * *}$ & $-0.2796^{* * *}$ \\
\hline & $(0.000)$ & $(0.000)$ \\
\hline & 0.007 & 0.064 \\
\hline \multirow[t]{3}{*}{ FC Dummy } & $-0.0700^{* * *}$ & $-0.0817^{* * *}$ \\
\hline & $(0.000)$ & $(0.000)$ \\
\hline & 0.008 & 0.011 \\
\hline \multirow[t]{3}{*}{$\mathrm{MP}(1)^{*} \mathrm{FC}$} & $-0.0375^{* * *}$ & $-0.3920^{* * *}$ \\
\hline & $(0.002)$ & $(0.000)$ \\
\hline & 0.012 & 0.083 \\
\hline \multirow[t]{3}{*}{$\mathrm{MP}(2)^{*} \mathrm{FC}$} & $-0.0387^{* * *}$ & $-0.5030^{* * *}$ \\
\hline & $(0.000)$ & $(0.000)$ \\
\hline & 0.009 & 0.085 \\
\hline \multirow[t]{3}{*}{$\mathrm{MP}(3)^{*} \mathrm{FC}$} & 0.0128 & $-0.1532 *$ \\
\hline & $(0.287)$ & $(0.055)$ \\
\hline & 0.012 & 0.080 \\
\hline \multirow[t]{3}{*}{$\mathrm{MP}(4)^{*} \mathrm{FC}$} & 0.0044 & $0.1936^{* *}$ \\
\hline & $(0.630)$ & $(0.026)$ \\
\hline & 0.009 & 0.087 \\
\hline \multirow[t]{3}{*}{ Constant } & $0.0584^{* * *}$ & $0.0665^{* * *}$ \\
\hline & $(0.000)$ & $(0.000)$ \\
\hline & 0.005 & 0.008 \\
\hline Observations & 50,349 & 25,148 \\
\hline R-squared & 0.004 & 0.008 \\
\hline $\mathrm{F}$ & 21.43 & 21.89 \\
\hline \multicolumn{3}{|l|}{ pval in parentheses } \\
\hline${ }^{* * *} p<0.01,{ }^{* *} p<0.05,{ }^{*} p<0.1$ & & \\
\hline
\end{tabular}

Source: my own calculations 


\section{Conclusion and Extensions}

The literature on the impact of monetary policy shocks agrees that policy change has real effects on firms. However, none address the impact on financially constrained firms' with heterogeneous fiscal years and thus spending patterns in response to continuous policy shocks. Other research shows that firms differ based on financial constraints regarding their access to capital, inventory growth, stock returns, and sensitivity to cash flows. My analysis adds to the existing literature by providing evidence that firms that are considered financially constrained do react adversely in their capital expenditures when there are exogenous policy shocks.

I find some consistent results across the three time horizons and two policy shock measurements that support my hypothesis that constrained firms indeed react more adversely in their fixed investment growth when policy shocks occur. The asset size classification indicates that shocks within the first year, either defined over 6-month intervals or over the whole year, negatively impact this investment growth in an opposing manner. For positive monetary policy shocks, the timeframe that yields significant reactions is consistent with the accepted idea that monetary policy has a 6- to 9-month lag in its effect on macroeconomic data. I believe that my approach provides statistical evidence that firms facing difficulty raising outside capital invest differently in response to monetary policy shocks. It may be impossible to quantify these constraints, but the proxy of asset size does a good job at highlighting this behavior that constrained firms are more sensitive to shifts in monetary policy. 


\section{References}

1. Almeida, Heitor, and Murillo Campello (2006). "Financing Constraints, Asset Tangibility, and Corporate Investment." National Bureau of Economic Research, Working Paper 12087

2. Almeida, H., Campello, M., \& Weisbach, M. S. (2004). The cash flow sensitivity of cash. The Journal of Finance, 59(4), 1777-1804.

3. Alti, A. (2003). How sensitive is investment to cash flow when financing is frictionless?. The Journal of Finance, 58(2), 707-722.

4. Bernanke, B. S., \& Blinder, A. S. (1992). The federal funds rate and the channels of monetary transmission. The American Economic Review, 901921.

5. Bernanke, B. S., \& Gertler, M. (1995). Inside the Black Box: The Credit Channel of Monetary Policy. The Journal of Economic Perspectives, 9(4), 2748.

6. Blinder, A. S., \& Maccini, L. J. (1991). Taking stock: a critical assessment of recent research on inventories. The journal of economic perspectives, 5(1), 7396.

7. Campello, Murillo, and Long Chen. "Are financial constraints priced? Evidence from firm fundamentals and stock returns." Journal of Money, Credit and Banking 42.6 (2010): 1185-1198.

8. Chirinko, R. S. (1993). Business fixed investment spending: Modeling strategies, empirical results, and policy implications. Journal of Economic literature, 31(4), 1875-1911.

9. Christiano, L. J., Eichenbaum, M., \& Evans, C. (1996). The Effects of Monetary Policy Shocks: Evidence from the Flow of Funds. The Review of Economics and Statistics, 78(1), 16-34.

10. Cleary, S. (1999). The relationship between firm investment and financial status. The Journal of Finance, 54(2), 673-692.

11. Ehrmann, M., \& Fratzscher, M. (2004). Taking stock: Monetary policy transmission to equity markets.

12. Fazzari, S. M., Hubbard, R. G., Petersen, B. C., Blinder, A. S., \& Poterba, J. M. (1988). Financing constraints and corporate investment. Brookings papers on economic activity, 1988(1), 141-206.

13. Fazzari, S. M., \& Petersen, B. C. (1993). Working capital and fixed investment: new evidence on financing constraints. The RAND Journal of Economics, 328-342.

14. Friedman, M., \& Schwartz, A. J. (1963). Money and Business Cycles. The Review of Economics and Statistics, 45(1 Part 2), 32-64.

15. Gertler, M., \& Gilchrist, S. (1994). Monetary Policy, Business Cycles, and the 
Behavior of Small Manufacturing Firms. Quarterly Journal of Economics, 109(2), 309-340.

16. Hodrick, R. J., \& Prescott, E. C. (1997). Postwar US business cycles: an empirical investigation. Journal of Money, credit, and Banking, 1-16.

17. Kaplan, S. N., \& Zingales, L. (1997). Do investment-cash flow sensitivities provide useful measures of financing constraints? The Quarterly Journal of Economics, 169-215.

18. Kashyap, A. K., Stein, J. C., \& Lamont, O. (1994). Credit Conditions and the Cyclical Behavior of lnventories. The Quarterly Journal of Economics 109 (1994), 565-592

19. Oliner, S. D., \& Rudebusch, G. D. (1996). Monetary policy and credit conditions: evidence from the composition of external finance: comment. The American Economic Review, 86(1), 300-309.

20. Romer, Christina D., and David H. Romer. "Does monetary policy matter? A new test in the spirit of Friedman and Schwartz." NBER Macroeconomics Annual 1989, Volume 4. MIT Press, 1989. 121-184.

21. Romer, C. D., \& Romer, D. H. (2004). A New Measure of Monetary Shocks: Derivation and Implications. American Economic Review 94 (4), 1055-1084.

22. Sims, C. A. (1972). Money, income, and causality. The American economic review, 62(4), 540-552.

23. Winter, J. (1998) Does Firms' Financial Status Affect Plant-Level Investment and Exit Decision. University of Mannheim 